\title{
Quality of life and risk of depression in the youngest-old and middle-old women and men
}

\author{
Jakość życia a ryzyko depresji u młodszych i starszych kobiet i mężczyzn \\ w wieku senioralnym
}

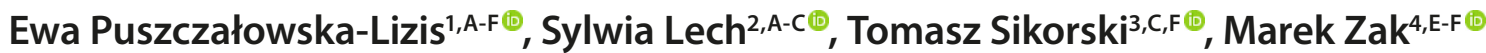 \\ ${ }^{1}$ University of Rzeszow, Medical College, Institute of Health Sciences, Rzeszow, Poland \\ ${ }^{2}$ Medical Centre 'NOVI-MED', Non-Public Health Care Institution, Łancut, Poland \\ ${ }^{3}$ Doctoral School, Jan Kochanowski University, Kielce, Poland \\ ${ }^{4}$ Collegium Medicum, Institute of Health Sciences, Jan Kochanowski University, Kielce, Poland \\ A - Research concept and design, B - Collection and/or assembly of data, C-Data analysis and interpretation, \\ $D$ - Writing the article, E-Critical revision of the article, F- Final approval of the article
}

Puszczałowska-Lizis E, Lech S, Sikorski T, Zak M. Quality of life and risk of depression in the youngest-old and middle-old women and men. Med Og Nauk Zdr. 2021; 27(3): 291-296. doi: 10.26444/monz/141293

\begin{abstract}
Introduction and objective. The currently observed progressive aging of societies has an impact on the occurrence of problems affecting the quality of life in many spheres. While focused on a mixed gender population, deliberately stratified into the youngest-oldest and middle-aged individuals, the study aimed to determine whether their subjective assessment of overall quality of life was in any way correlated with the risk of depression.
\end{abstract}

Materials and method. A study sample of 164 free-living community dwellers aged 65-84 years was investigated with the use of WHOQOL-BREF and GDS-15 surveys. The data collected was subsequently analysed by Chi-square test, Student's t test, Mann Whitney U test, and Spearman rank correlation.

Results. Significant differences were established in the overall quality of life in terms of select psychological variables in women from Groups I and II ( $p=0.006)$. In the groups stratified by age angender, significant negative correlations were noted $(p<0.001)$ between respective domains under study.

Conclusions. Women from the youngest-oldest group rated their quality of life higher in the psychological domain, compared with the middle-aged group. Neither age nor gender differentiated individual susceptibility to depression, even though approx. $30 \%$ of all respondents were ultimately established as being at such risk. Individuals established as less prone to depression rated their overall quality of life as higher in the respective domains. The respondents' subjective assessment indicated no correlation with the risk of depression.

\section{Key words}

quality of life, community dwellers, public health

\section{Streszczenie}

Wprowadzenie i cel pracy. Obserwowany w obecnych czasach postępujący proces starzenia się społeczeństw ma wpływ na powstawanie problemów dotyczących wielu sfer życia, które składają się na jego jakość. Koncentrując się na populacji seniorów mieszanej płci, celowo podzielonej na młodszych i starszych, podjęto próbę ustalenia, czy ich subiektywna ocena ogólnej jakości życia jest skorelowana z ryzykiem depresji. Materiał i metody. Populację liczącą 164 wolno żyjących mieszkańców społeczności (w wieku 65-84 lata) poddano sondażowi diagnostycznemu za pomocą kwestionariuszy WHOQOL-BREF i GDS-15; uzyskane dane poddano analizie przy użyciu testów chi $^{2}$, t-Studenta, U Manna-Whitneya i korelacji rang Spearmana.

Wyniki. Stwierdzono statystycznie istotne różnice pod względem jakości życia w domenie psychologicznej u kobiet z grupy I i II $(p=0,006)$. W grupach wyodrębnionych ze względu na wiek i płeć odnotowano statystycznie istotne, ujemne korelacje między wynikami uzyskanymi w poszczególnych domenach na podstawie WHOQOL-BREF a rezultatami skali GDS-15 $(p<0,001)$.

Wnioski. Kobiety z grupy I lepiej oceniły jakość własnego życia w domenie psychologicznej w porównaniu do kobiet z grupy II. Wiek i płeć nie różnicowały skłonności do depresji szacowanej na podstawie GDS-15. Około 30\% badanych seniorów jest zagrożonych ryzykiem depresji, niezależnie od wieku i płci. Osoby przejawiające mniejszą skłonność do depresji lepiej oceniają jakość własnego życia w poszczególnych domenach WHOQOL-BREF. Subiektywna ocena jakości własnego życia i ogólne postrzeganie własnego zdrowia przez badanych nie wykazują związków z ryzykiem depresji.

\section{Słowa kluczowe}

jakość życia, mieszkańcy społeczności, zdrowie publiczne 


\section{INTRODUCTION}

The currently observed progressive aging of societies has an impact on the occurrence of problems in many spheres of life affecting its quality. Quality of life, which is the resultant of emotional condition, physical health, and functional fitness in everyday life, is an important issue, especially in relation to the elderly [1-4].

The term 'Quality of Life' (QoL) lends itself to more than one interpretation, and when used, it does not always have the same meaning, because it is 'subject to being affected by the context in which the QoL is being considered', assert the authors of a scoping review of studies on the subject with the intriguing title 'Defining Quality of Life: A Wild-Goose Chase?' [5]. This must apparently have been due to acknowledgement of the substantial complexity of the task at hand. Indeed, QoL seems to be more of an 'umbrella' term, rather than an academic concept of a specifically construed meaning. Having said that, the authors of yet another scoping review refer to the subject as constituting an essential sub-category within the QoL issue of steadily-burgeoning proportions in terms of the actual size of the populations involved, i.e. Quality of Life in Older Ages.

The quality of life of elderly people has become relevant with the demographic shift that has resulted in the greying of population. There are indications that concepts and concerns related to quality of life in older ages are different from the general population $[1,2]$. This prompted the authors of the current study to investigate the specifics of the QoL issue in older ages in terms of its select key domains, i.e. physical health, psychological, social relationships, and the environmental domain. The study also aimed to establish whether subjective self-assessment of QoL in older aged individuals was in any way linked with the risk of depression. The study therefore focused on the youngest-oldest and middle-aged men and women, thus effectively acknowledging that older age was not just a single, broad category of commonly shared characteristics, but a fairly broad spectrum of different aspects in need of considerate discrimination. To this end, the following research questions were addressed:

1. Do age and gender differentiate the subjects' subjective assessment of overall quality of their life and perception of their overall health status, in conformity with the four selected WHOQOOL-BREF survey domains?

2. Do age and gender differentiate individual susceptibility to depression, as determined by the GDS-15 scale?

3. What proportion of the older adults under study remains at risk of depression?

4. How age, gender, and individual susceptibility to depression are correlated in older adults?

5. Is subjective assessment of the overall quality of life in any way correlated with the severity of depression in older adults?

\section{MATERIALS AND METHOD}

Participants. The study covered 164 free-living community dwellers, aged $65-84$ years. The respondents were randomly selected from among those aged 65 years and over who were residents at a purpose-built housing estate for seniors. The following inclusion criteria were applied: age range 65-84 years and written informed consent to participate in the study. Persons affected by severe cognitive impairment or hampered by severe dependency were considered ineligible.

Two study samples was split into two age groups. The first group consisted of the individuals aged 65-74 years (youngest-old), and comprised 48 women and 39 men, whereas the second group came within the 75-84 age range (middle-old), i.e. 40 women and 37 men. Table 1 presents the socio-demographic and clinical characteristics of the respondents.

Table 1. Socio-demographic and clinical characteristics of the respondents

\begin{tabular}{|c|c|c|c|}
\hline Variable & Group I & Group II & \\
\hline \multicolumn{4}{|l|}{ Age (years), $\bar{x} \pm S D$} \\
\hline Women & $68.98 \pm 2.78$ & $78.41 \pm 2.62$ & $\mathrm{t}=-13.73 ; \mathrm{p}<0.001^{*}$ \\
\hline Men & $68.38 \pm 3.00$ & $78.95 \pm 2.73$ & $\mathrm{t}=-15.22 ; \mathrm{p}<0.001^{*}$ \\
\hline \multicolumn{4}{|l|}{ Gender, n (\%) } \\
\hline Women & $48(55.0)$ & $40(52.0)$ & \multirow{2}{*}{$x^{2}(1)=0.17 ; p=0.679$} \\
\hline Men & $39(45.0)$ & $37(48.0)$ & \\
\hline \multicolumn{4}{|l|}{ Level of education, $n$ (\%) } \\
\hline Primary & $8(9.0)$ & $23(30.0)$ & \multirow{4}{*}{$x^{2}(3)=14.28 ; p=0.003^{*}$} \\
\hline Vocational & $26(30.0)$ & $25(32.0)$ & \\
\hline Secondary & $39(45.0)$ & $19(25.0)$ & \\
\hline Higher & $14(16.0)$ & $10(13.0)$ & \\
\hline \multicolumn{4}{|l|}{ Marital status, n (\%) } \\
\hline Single & $13(15.0)$ & $13(17.0)$ & \multirow{4}{*}{$x^{2}(3)=2.45 ; p=0.484$} \\
\hline Married & $43(49.0)$ & $29(38.0)$ & \\
\hline Divorced & $7(8.0)$ & $9(12.0)$ & \\
\hline Widowed & $24(28.0)$ & $26(33.0)$ & \\
\hline \multicolumn{4}{|l|}{ Housing situation., n (\%) } \\
\hline Living alone & $26(30.0)$ & $20(26.0)$ & \multirow{2}{*}{$x^{2}(1)=0.31 ; p=0.577$} \\
\hline Living with a family & $61(70.0)$ & $57(74.0)$ & \\
\hline \multicolumn{4}{|l|}{ Chronic diseases, n (\%) } \\
\hline Yes & $58(67.0)$ & $65(84.0)$ & \multirow{2}{*}{$x^{2}(1)=6.86 p=0.009^{*}$} \\
\hline No & $29(33.0)$ & $12(16.0)$ & \\
\hline
\end{tabular}

${ }^{*} \alpha=0.05$.

Abbreviations: $\mathrm{n}$ - number of subjects; \% - percent of subjects; $\bar{x}$ - arithmetic mean; SD standard deviation; $t-$ value of the Student's $t$ test statistic; $X^{2}-$ value of the Chi-square test statistic; $p$ - probability value.

Design. Socio-demographic and clinical data were collected through a self-designed questionnaire. The following research tools of choice were applied:

- a shortened version of the quality of life assessment survey WHOQOL-BREF. The questionnaire is comprised of 26 questions designed to assess the quality of life in the four key domains, i.e. physical health, psychological, social relationships, and environmental domain. There are also two items assessed separately, i.e. Question 1 addresses individual perception of the overall quality of life, whereas Question 2 addresses the individual perception of overall health status. The responses were assessed on a 5-point scale (score ranging 1-5 points for each question). Respective domain scores were scaled in a positive direction (i.e. the higher scores indicated the higher quality of life) [6].

- 15-item Geriatric Depression Scale - GDS-15, a self-report measure of depression in elderly adults. The scale is comprised of $15 \mathrm{YES} / \mathrm{NO}$ questions. One point was assigned to each response and a cumulative score was then rated on 
a scoring grid. The following ranges were accounted for in the rating of the results: $0-5$ points: normal; $6-10$ points: mild depressives; 11-15 points: severe depressives [7].

The research was carried out with the use of a direct probing method. The the survey questionnaires were distributed among the respondents during meetings in local seniors clubs. All participants were given specific instructions on how to fill in the questionnaires, and returned them as soon as they had responded to all the questions. All procedures were carried out in full compliance with the Declaration of Helsinki. The study protocol was approved by the Ethical Review Board of Rzeszów University (No. 4/04/2020).

Analysis. Consistency of variables with normal distribution was verified by means of the Shapiro-Wilk test. Analysis was carried out using the Pearson Chi-square test, Student's t test for independent samples, Mann Whitney U test and Spearman rank correlation. The results were considered statistically significant on the predetermined significance level $\alpha=0.05$. The STATISTICA application was used to process test results.

\section{RESULTS}

Table 2 shows the results of the respondents' subjective assessment of overall quality of their life, and overall perception of their health status. These data indicate no statistically significant age- and gender-related differences in terms of assessing overall perception of quality of life and overall perception of individual health status.

Table 2. Individual perception of overall quality of life and health status, as assessed by WHOQOL-BREF survey

\begin{tabular}{|c|c|c|c|c|c|c|c|}
\hline \multicolumn{2}{|c|}{ Group } & $\bar{x} \pm \mathrm{SD}$ & Max-min & Q25 & $\mathrm{Me}$ & Q75 & $\begin{array}{c}\text { Mann } \\
\text { Whitney } \\
\text { U test }\end{array}$ \\
\hline \multicolumn{8}{|c|}{ Individual's overall perception of quality of life } \\
\hline & Women & $70.00 \pm 16.50$ & $100.00-20.00$ & 60.00 & 60.00 & 80.00 & \multirow{2}{*}{$\begin{array}{c}Z=0.44 \\
p=0.657\end{array}$} \\
\hline & Men & $71.79 \pm 13.55$ & $100.00-40.00$ & 60.00 & 80.00 & 80.00 & \\
\hline \multirow{2}{*}{ II } & Women & $71.00 \pm 11.94$ & $100.00-80.00$ & 60.00 & 40.00 & 80.00 & \multirow{2}{*}{$\begin{array}{l}Z=-1.08 \\
p=0.279\end{array}$} \\
\hline & Men & $74.59 \pm 16.77$ & $100.00-80.00$ & 60.00 & 40.00 & 80.00 & \\
\hline \multirow{2}{*}{\multicolumn{2}{|c|}{$\begin{array}{l}\text { Mann Whitney } \\
\text { U test }\end{array}$}} & Women I-II & \multicolumn{5}{|c|}{$Z=0.32 ; p=0.743$} \\
\hline & & Men I-II & \multicolumn{5}{|c|}{$Z=-0.89 ; p=0.374$} \\
\hline
\end{tabular}

Individual's overall perception of health

\begin{tabular}{|c|c|c|c|c|c|c|c|}
\hline & Women & $66.25 \pm 17.09$ & $100.00-40.00$ & 60.00 & 60.00 & 80.00 & \multirow{2}{*}{$\begin{array}{l}Z=0.56 \\
p=0.573\end{array}$} \\
\hline & Men & $66.67 \pm 19.10$ & 100.00-20.00 & 60.00 & 80.00 & 80.00 & \\
\hline \multirow{2}{*}{ | } & Women & $66.00 \pm 15.16$ & $100.00-40.00$ & 60.00 & 60.00 & 80.00 & \multirow{2}{*}{$\begin{array}{l}Z=0.10 \\
p=0.914\end{array}$} \\
\hline & Men & $65.41 \pm 17.42$ & 100.00-20.00 & 60.00 & 60.00 & 80.00 & \\
\hline \multirow{2}{*}{\multicolumn{2}{|c|}{$\begin{array}{l}\text { Mann Whitney } \\
\text { U test }\end{array}$}} & Women I-II & \multicolumn{5}{|c|}{$Z=0.17 ; p=0.860$} \\
\hline & & Men I-II & \multicolumn{5}{|c|}{$Z=0.51 ; p=0.606$} \\
\hline
\end{tabular}

Abbreviations: $\bar{x}$ - arithmetic mean; SD - standard deviation; max - maximum value; min minimum value; $Q_{25}$ - lower quartile; Me - median; $Q_{75}$ - upper quartile; $Z$ - value of the MannWhitney $U$ test statistic; $p$ - probability value.

There were statistically significant differences in terms of overall quality of life in the psychological domain in women from Groups I and II ( $\mathrm{p}=0.006)$. The data indicate that overall quality of life in this domain was rated higher by women
Table 3. Comparison of overall quality of life between the study groups in four domains, as assessed by WHOQOL-BREF survey.

\begin{tabular}{|c|c|c|c|c|c|c|c|}
\hline Group & & $\bar{x} \pm \mathrm{SD}$ & Max-min & Q25 & $\mathrm{Me}$ & Q75 & $\begin{array}{c}\text { Mann } \\
\text { Whitney } \\
\text { U test }\end{array}$ \\
\hline \multicolumn{8}{|c|}{ Physical health domain } \\
\hline & Women & $55.21 \pm 9.96$ & $88.00-31.00$ & 50.00 & 56.00 & 63.00 & \multirow{2}{*}{$\begin{array}{l}Z=-1.46 \\
p=0.143\end{array}$} \\
\hline & Men & $50,82 \pm 13.12$ & $75.00-13.00$ & 44.00 & 56.00 & 63.00 & \\
\hline \multirow{2}{*}{ | } & Women & $53.70 \pm 8.98$ & $69.00-31.00$ & 50.00 & 56.00 & 63.00 & \multirow{2}{*}{$\begin{array}{c}Z=1.59 \\
p=0.109\end{array}$} \\
\hline & Men & $50.68 \pm 8.21$ & $63.00-38.00$ & 44.00 & 50.00 & 56.00 & \\
\hline \multirow{2}{*}{\multicolumn{2}{|c|}{$\begin{array}{l}\text { Mann Whitney } \\
\text { U test }\end{array}$}} & Women I-II & \multicolumn{5}{|c|}{$Z=-0.62 ; p=0.532$} \\
\hline & & Men I-II & \multicolumn{5}{|c|}{$\mathrm{Z}=0.29 ; p=0.771$} \\
\hline
\end{tabular}

Psychological domain

\begin{tabular}{|c|c|c|c|c|c|c|c|}
\hline \multirow{2}{*}{1} & Women & $61.96 \pm 11.13$ & $88.00-44.00$ & 56.00 & 63.00 & 69.00 & \multirow{2}{*}{$\begin{array}{l}Z=-1.21 \\
p=0.225\end{array}$} \\
\hline & Men & $58.49 \pm 12.97$ & $81.00-31.00$ & 44.00 & 63.00 & 69.00 & \\
\hline \multirow{2}{*}{ II } & Women & $55.00 \pm 10.75$ & $81.00-31.00$ & 50.00 & 56.00 & 56.00 & \multirow{2}{*}{$\begin{array}{l}Z=-1.10 \\
p=0.267\end{array}$} \\
\hline & Men & $57.59 \pm 8.78$ & $81.00-44.00$ & 50.00 & 56.00 & 63.00 & \\
\hline \multirow{2}{*}{\multicolumn{2}{|c|}{$\begin{array}{l}\text { Mann Whitney } \\
\text { U test }\end{array}$}} & Women I-II & \multicolumn{5}{|c|}{$Z=2.74 ; p=0.006^{*}$} \\
\hline & & Men I-II & \multicolumn{5}{|c|}{$Z=0.44 ; p=0.658$} \\
\hline \multicolumn{8}{|c|}{ Social relationships domain } \\
\hline \multirow{2}{*}{ I } & Women & $62.25 \pm 18.05$ & $100.00-19.00$ & 50.00 & 69.00 & 75.00 & \multirow{2}{*}{$\begin{array}{l}Z=0.05 \\
p=0.959\end{array}$} \\
\hline & Men & $61.18 \pm 21.69$ & $94.00-6.00$ & 44.00 & 69.00 & 75.00 & \\
\hline \multirow{2}{*}{ II } & Women & $58.30 \pm 17.56$ & $100.00-25.00$ & 50.00 & 53.00 & 69.00 & \multirow{2}{*}{$\begin{array}{l}Z=-0.58 \\
p=0.561\end{array}$} \\
\hline & Men & $58.08 \pm 14.57$ & $94.00-19.00$ & 50.00 & 56.00 & 69.00 & \\
\hline \multirow{2}{*}{\multicolumn{2}{|c|}{$\begin{array}{l}\text { Mann Whitney } \\
\text { U test }\end{array}$}} & Women I-II & \multicolumn{5}{|c|}{$Z=-1.55 ; p=0.119$} \\
\hline & & Men I-II & \multicolumn{5}{|c|}{$Z=1.03 ; p=0.299$} \\
\hline
\end{tabular}

Environmental domain

\begin{tabular}{|c|c|c|c|c|c|c|c|}
\hline & Women & $65.23 \pm 14.35$ & $100.00-38.00$ & 56.00 & 63.00 & 75.00 & \multirow{2}{*}{$\begin{array}{l}Z=-1.42 \\
p=0.154\end{array}$} \\
\hline & Men & $60.36 \pm 13.43$ & $88.00-31.00$ & 50.00 & 63.00 & 69.00 & \\
\hline \multirow{2}{*}{ II } & Women & $60.33 \pm 13.62$ & $94.00-38.00$ & 50.00 & 56.00 & 69.00 & \multirow{2}{*}{$\begin{array}{l}Z=0.95 \\
p=0.337\end{array}$} \\
\hline & Men & $57.89 \pm 9.07$ & $81.00-50.00$ & 50.00 & 56.00 & 63.00 & \\
\hline \multirow{2}{*}{\multicolumn{2}{|c|}{$\begin{array}{l}\text { Mann Whitney } \\
\text { U test }\end{array}$}} & Women I-II & \multicolumn{5}{|c|}{$Z=-1.68 ; p=0.092$} \\
\hline & & Men I-II & \multicolumn{5}{|c|}{$Z=0.74 ; p=0.454$} \\
\hline
\end{tabular}

* $\mathrm{a}=0.05$.

Abbreviations: $\bar{x}$ - arithmetic mean; SD - standard deviation; $\max$ - maximum value; $\min -$ minimum value; $Q_{25}$ - lower quartile; $M e$ - median; $Q_{75}$ - upper quartile; $Z$ - value of the MannWhitney $U$ test statistic; $p$ - probability value

from Group I (Tab. 3).

The data in Table 4 indicate no statistically significant differences in the GDS-15 results between women and men allocated to respective study groups, neither between women from Group I and II, nor men from Group I and II.

Table 4. Comparison of the GDS-15 scale results between women and men allocated to respective study group

\begin{tabular}{|c|c|c|c|c|c|c|c|}
\hline Group & & $\bar{x} \pm \mathrm{SD}$ & Max-min & Q25 & Me & Q75 & $\begin{array}{c}\text { Mann Whitney } \\
\text { U test }\end{array}$ \\
\hline \multirow{2}{*}{ I } & Women & $3.60 \pm 2.85$ & $10.00-0.00$ & 2.00 & 3.00 & 5.00 & \multirow{2}{*}{$\begin{array}{c}Z=0.52 \\
p=0.596\end{array}$} \\
\hline & Men & $4.38 \pm 3.64$ & $11.00-0.00$ & 1.00 & 3.00 & 8.00 & \\
\hline \multirow{2}{*}{ II } & Women & $4.88 \pm 3.26$ & $14.00-0.00$ & 2,00 & 5.00 & 7.00 & \multirow{2}{*}{$\begin{array}{c}Z=0.70 \\
p=0.482\end{array}$} \\
\hline & Men & $4.30 \pm 2.73$ & $12.00-0.00$ & 2,00 & 4.00 & 6.00 & \\
\hline \multirow{2}{*}{\multicolumn{2}{|c|}{$\begin{array}{l}\text { Mann Whitney } \\
\text { U test }\end{array}$}} & Women I-II & \multicolumn{5}{|c|}{$Z=-1.78 ; p=0.073$} \\
\hline & & Men I-II & \multicolumn{5}{|c|}{$Z=-0.48 ; p=0.626$} \\
\hline
\end{tabular}

Abbreviations: $\bar{x}$ - arithmetic mean; SD - standard deviation; max - maximum value; $\min$ minimum value; $Q_{25}$ - lower quartile; $M e$ - median; $Q_{75}$ - upper quartile; $Z$ - value of the MannWhitney $\mathrm{U}$ test statistic; $\mathrm{p}$ - probability value. 
Table 5. Dependences between the age and gender categories and severity of depression, as assessed against the GDS-15 scale

\begin{tabular}{|c|c|c|c|c|}
\hline Variable & Normal & Mild depressives & Severe depressives & Chi-square test \\
\hline \multicolumn{5}{|c|}{ Women, n (\%) } \\
\hline Group I & $37(77.0)$ & $11(23.0)$ & $0(0.0)$ & \multirow{2}{*}{$\begin{array}{c}x^{2}(2)=2.97 \\
p=0.225\end{array}$} \\
\hline Group II & $25(62.0)$ & $14(36.0)$ & $1(2.0)$ & \\
\hline \multicolumn{5}{|c|}{ Men, n (\%) } \\
\hline Group I & $26(67.0)$ & $11(28.0)$ & $2(5.0)$ & \multirow{2}{*}{$\begin{array}{c}x^{2}(2)=0.32 \\
p=0.848\end{array}$} \\
\hline Group II & $26(70.0)$ & $10(27.0)$ & $1(3.0)$ & \\
\hline \multicolumn{5}{|c|}{ Group I, n (\%) } \\
\hline Women & $37(77.0)$ & $11(23.0)$ & $0(0.0)$ & \multirow{2}{*}{$\begin{array}{c}x^{2}(2)=3.02 \\
p=0.220\end{array}$} \\
\hline Men & $26(67.0)$ & $11(28.0)$ & $2(5.0)$ & \\
\hline \multicolumn{5}{|c|}{ Group II, n (\%) } \\
\hline Women & $25(63.0)$ & $14(35.0)$ & $1(2.0)$ & \multirow{2}{*}{$\begin{array}{c}x^{2}(2)=0.57 \\
p=0.751\end{array}$} \\
\hline Men & $26(70.0)$ & $10(27.0)$ & $1(3.0)$ & \\
\hline
\end{tabular}

Abbreviations: $\mathrm{n}$ - number of subjects; \% - percent of subjects; $\mathrm{x}^{2}$ - value of the Chi-square test statistic; $\mathrm{p}$ - probability value

The data in Table 5 indicate that most respondents were not at risk of depression; nor were there any statistically significant associations between age and gender categories, and the severity of depression.

Data in Table 6 indicate the presence of statistically significant negative correlations between the results obtained in individual domains, as assessed by the WHOQOL-BREF survey and the GDS-15 scale. The associations were noted in both the age and gender groups.

\section{DISCUSSION}

The results obtained in the current study, together with a review of published studies on the subject, indicate that senior age poses a number of challenges to the healthcare policies in place, especially with regard to men and women of senior age, irrespective of specific age ranges.

The principal value of the present study consists in the fact that all analyses took into account stratification by age (i.e. allocation of the study subjects into the youngest-oldest and middle-old age ranges), and gender. This in turn provided sufficient grounds to conclude that in the case of women, the overall quality of life actually deteriorated with age in the psychological domain.

Analysis of the inter-gender differences in subjective assessment of health-related quality of life in Iranian nationals aged 60-90 years, as studied by Hajian-Tilaki et al. [8], indicated that female respondents were characterised by significantly worse ratings than men. Similar conclusions were drawn by Wilhelmson et al. [9] in a study of seniors aged 80 years or older in a Swedish population, assisted by the Fugl-Meyer's LiSat-11 tool, as well as by Campos et al. [10], based on data sourced from the studies of seniors in Brazil, and Janiszewska [11], who reported the scores obtained through subjective assessment of health in the individuals over 65 years of age living in the EU countries. $\mathrm{Ng}$ et al. [12], while using a self-designed, five-point scale among the oldest-old individuals, concluded that women seniors living in China were more satisfied with life than men at the corresponding age. Similar conclusions were reached by Liu [13] and Zhou et al. [14].
Table 6. Correlations between overall quality of life, as assessed by the WHOQOL-BREF survey, and the severity of depression assessed by the GDS-15 scale

\begin{tabular}{|c|c|c|c|}
\hline \multicolumn{2}{|c|}{ Pair of variables } & \multirow[t]{2}{*}{$R$} & \multirow[t]{2}{*}{$\mathrm{p}$} \\
\hline Group & & & \\
\hline \multirow{6}{*}{ Group I } & Individual perception of overall quality of life \& GDS-15 & 0.07 & 0.508 \\
\hline & Individual perception of overall health status \& GDS-15 & -0.05 & 0.640 \\
\hline & Physical health domain \& GDS-15 & -0.26 & $0.014^{*}$ \\
\hline & Psychological domain \& GDS-15 & -0.46 & $<0.001^{*}$ \\
\hline & Social relationships domain \& GDS-15 & -0.45 & $<0.001^{*}$ \\
\hline & Environmental domain \& GDS-15 & -0.48 & $<0.001^{*}$ \\
\hline \multirow{6}{*}{ Group II } & Individual perception of overall quality of life \& GDS-15 & 0.16 & 0.174 \\
\hline & Individual perception of overall health status \& GDS-15 & 0.15 & 0.179 \\
\hline & Physical health domain \& GDS-15 & -0.54 & $<0.001^{*}$ \\
\hline & Psychological domain \& GDS-15 & -0.33 & $0.003^{*}$ \\
\hline & Social relationships domain \& GDS-15 & -0.46 & $<0.001^{*}$ \\
\hline & Environmental domain \& GDS-15 & -0.59 & $<0.001^{*}$ \\
\hline \multicolumn{4}{|l|}{ Gender } \\
\hline \multirow{6}{*}{ Women } & Individual perception of overall quality of life \& GDS-15 & 0.06 & 0.585 \\
\hline & Individual perception of overall health status \& GDS-15 & 0.01 & 0.913 \\
\hline & Physical health domain \& GDS-15 & -0.42 & $<0.001^{*}$ \\
\hline & Psychological domain \& GDS-15 & -0.43 & $<0.001^{*}$ \\
\hline & Social relationships domain \& GDS & -0.47 & $<0.001^{*}$ \\
\hline & Environmental domain \& GDS-15 & -0.54 & $<0.001^{*}$ \\
\hline \multirow{6}{*}{ Men } & Individual perception of overall quality of life \& GDS-15 & 0.16 & 0.164 \\
\hline & Individual perception of overall health status \& GDS-15 & 0.06 & 0.599 \\
\hline & Physical health domain \& GDS-15 & -0.39 & $<0.001^{*}$ \\
\hline & Psychological domain \& GDS-15 & -0.45 & $<0.001^{*}$ \\
\hline & Social relationships domain \& GDS-15 & -0.50 & $<0.001^{*}$ \\
\hline & Environmental domain \& GDS-15 & -0.59 & $<0.001^{*}$ \\
\hline
\end{tabular}

${ }^{*} \mathrm{a}=0.05$

$\mathrm{R}$ - Spearman's rank correlation coefficient; $\mathrm{p}$ - probability value.

Taking into account the overall quality of life, as assessed against the WHOQOL-BREF survey, Waszkiewicz et al. [15] found that seniors allocated to the older age groups were characterized by greater satisfaction with their quality of life, whereas in Frąckowiak's [16] study, the individual sense of overall quality of one's life decreased with age. Discrepant results were collected by Pacian et al. [17] who observed deterioration in the psychological domain scores up to the age of 75 years, followed by their subsequent improvement in individuals who exceeded this age threshold.

A review of studies addressing inter-gender quality-of-life comparisons also yielded inconsistent data. Kirchengast and Haslinger [18], Blay and Marchesoni [19], and Canković et al. [20], did not encounter statistically significant differences between men and women. In the current study, gender differentiated the quality of life only in the psychological domain (WHOQOL-BREF survey). The women allocated to the youngest-old group rated their quality of life higher in this domain, compared to those in the middle-old group. Similar scores in this domain were reported by Ganesh Kumar et al. [21] in their study on seniors in India, whereas Arslantas et al. [22] concluded against the scores collected in Turkey, whereby it was actually the men who boasted higher ratings in the subjective assessment of overall quality of life. 
The current study indicates that age and gender do not differentiate the subjects' subjective assessment of the quality of their lives and overall perception of their health status. With respect to age, Pawlikowska-Łagód et al. [23] arrived at similar conclusions in their study of 120 individuals aged 60-87 years, using the Ferrans and Powers Quality of Life Index, the same as Timoszyk-Tomczak and Bugajska [24] in assessing the SWLS the scores obtained in a study of 234 women and 119 men over 65 years of age.

Uma Devi et al. [25], and Nowicki et al. [26], however, obtained quite different results in noting that in seniors subjective perception of overall quality of life declined with age. On the other hand, the scores of the Life Satisfaction Index for the Third Age - Short Form (LSITA-SF), as reported by Mirczak and Pikuła [27], attested to a rise in the level of satisfaction with life in seniors along with age. The authors did not notice any association between gender and subjective quality of life. Likewise, Mudyń and Weiss [28] did not observe any inter-gender differences in terms of the SWLS scores in seniors from Krakow, Poland, while acknowledging higher ratings in the older age categories. The authors pointed out that although some stressors, e.g. those related to one's occupation, declined in retirement age, which may well have accounted for that particular improvement.

In the current study, neither age nor gender differentiated the subjects in their susceptibility to depression, as estimated by the GDS-15 scale. Quite different results were reported by Pacian et al. [17] while using of the same research tool. It was established that the risk of depression was higher in the older age groups. On the other hand, Forlani et al. [29] observed a drop in the risk of depression with age. Fidecki et al. [30] observed (against GDS-15) no effect of age, whereas the female gender was established to correlate with the risk of depression. Back and Lee [31] came to similar conclusions in their study of Korean seniors while using the CES-D, as did Lin and Wang [32] with regard to Taiwanese seniors.

The study by Lohman et al. [33] in the USA, also indicated a greater susceptibility to depression among women than men over 65 . The investigators attributed this to the association between depression and hormonal imbalance in women. Dalal and Agarwal [34] asserted that women demonstrated an increased risk of depression, mainly due to the altered biochemical processes in the brain, owing primarily to a drop in estrogen levels. Djukanović et al. [35], on the other hand, reported a higher frequency of depressive symptoms in Swedish male seniors (against GDS-15 scale), especially within the 75-80 age range. Park et al. [36] established no association between gender and the risk of depression in his study of South Korean seniors.

In the current study, approx. 30\% of the seniors were established as being at risk of depression, regardless of age and gender. Forlani et al. [29] reported the risk of depression in $25 \%$ of cognitively well-functioning individuals over 74 years of age. On the other hand, GDS-15 scores obtained by Djukanović et al. [35] indicated the risk of depression in $10 \%$ of the individuals representative of a population of seniors aged - 80 years living in Sweden. The GDS-15 scores obtained by Bartoszek et al. [37] in Poland, indicated the risk of depression with regard to $17 \%$ of seniors living in their home environment. Slusarska et al. [38] reported a moderate risk of depression in $14 \%$ of seniors remaining under the care of a community nurse, and the risk of severe depression in $5 \%$ of the respondents. Fidecki et al. [30] noted the risk of moderate depression (against GDS-15) in 35\% of rural residents over 65 years of age, and of severe depression in $9 \%$ of respondents.

An interesting issue consists in the linke between overall quality of life and the risk of geriatric (old age) depression. This study indicates that individuals less prone to depression rated overall quality of their life higher. On the other hand, the subjects' subjective assessment of overall quality of their lives and overall perception of their health status indicated no correlation with the risk of depression. Chang et al. [39], in a study focused on older adults recruited from community centres located in both the northern and southern parts of Taiwan, concluded that depression, as assessed by the GDS-15 scale, affected the scores in every domain of life, and all categories of the WHOQOL-BREF survey. On the other hand, Patten et al. [40] reported that the risk of depression decreased, as the seniors scored higher in the physical domain. The results reported by Campos et al. [10] indicated that female seniors who rated their own health status as satisfactory were less prone to depressive disorders. This particular finding may well contribute to formulating new priorities when planning public health and social care policies for individuals over the age of 65 . It conclusively highlights the need for extending specifically targeted psychological support, in conjunction with offering a wide range of supervised activities within the community, aimed at stimulating individual creativity and enhancing physical activity.

The data obtained by the study also highlight that an individual sense of inferior quality of life in respective domains is invariably correlated with the actual severity of depression, regardless of one's age and gender. This again highlights the need for target-oriented prevention, e.g. introduction of screening tests aimed at the early detection of the onset of depression in seniors, in conjunction with facilitating easy access to specialist treatment management in the outpatient units.

\section{CONCLUSIONS}

1. Age and gender were established as not differentiating between the respondents' subjective assessment of overall quality of their lives, and perception of their health status, even though this was the case with regard to the psychological domain (as assessed against the WHOQOL-BREF survey). Women from the youngest-old group rated their quality of life higher in this domain, compared to their middle-old group peers.

2. Age and gender did not differentiate individual susceptibility to depression, as assessed against the GDS-15 scale.

3. Approx. $30 \%$ of the respondents were established as being at risk of depression, regardless of age and gender.

4. Individuals less prone to depression rated their overall quality of life as higher in the respective WHOQOL-BREF domains. The respondents> subjective assessment of the overall quality of their lives and perception of their health status, indicated no correlation with the risk of depression. 


\section{REFERENCES}

1.Lee SB, Oh JH, Park JH, et al. Differences in youngest-old, middle-old, and oldest-old patients who visit the emergency department. Clin Exp Emerg Med. 2018; 5(4): 249-255.

2. Ganesh Kumar S, Majumdar A, Pavithra G. Quality of life (QOL) and its associated factors using WHOQOL-BREF among elderly in urban Puducherry, India. J Clin Diagn Res. 2014; 8(1): 54-57.

3. Canković S, Nikolić EA, Jovanović VM, Kvrgić S, Harhaji S, Radić I. Quality of life of elderly people living in a retirement home. Vojnosanit Pregl. 2016; 73(1): 42-46.

4. Puszczalowska-Lizis E, Flak K, Biskup M, et al. Physical activity of women after radical unilateral mastectomy and its impact on overall quality of life. Cancer Control. 2020; 27(1): 1-10.

5. Barcaccia B, Esposito G, Matarese M, et al. Defining quality of life: a wild-goose chase? EJOP. 2013; 9(1): 185-203.

6. Wołowicka L, Jaracz K. Polish version WHOQOL 100 i WHOQOLBREF. In: Wolowicka L, editor. Quality of life in medical sciences. Poznan: Medical Academy; 2001. p. 1-54.

7.Sheikh JI, Yesavage JA. Geriatric depression scale (GDS): Recent evidence and development of a shorter version. Clin Gerontol. 1986, 5(1-2): 165-173.

8. Hajian-Tilaki K, Heidari B, Hajian-Tilaki A. Are gender differences in health-related quality of life attributable to sociodemographic characteristics and chronic disease conditions in elderly people? Int J Prev Med. 2017; 8: 95.

9. Wilhelmson K, Fritzell E, Eklund K, et al. Life satisfaction and frailty among older adults. Health Psychol Res. 2013; 1(3): e32.

10. Campos AC, Ferreira E, Ferreira E. Gender and Quality of Life (AGEQOL) study: factors associated with good quality of life in older Brazilian community-dwelling adults. Health Qual Life Outcomes. $2014 ; 12: 166$.

11. Janiszewska A. The image of demographic old age in the countries of EU and the health of its inhabitants. Quality of Life of Old People - Selected Problems. 2015; 14: 25-48.

12. Ng ST, Tey NP, Asadullah MN. What matters for life satisfaction among the oldest-old? Evidence from China. PLoS One. 2017; 12(2): e0171799.

13. Liu J. Research on the elderlyıs life satisfaction and the influence factors - analysis based on National Baseline Data of China Health and Retirement Longitudinal Study (CHARLS). Sci Res Aging. 2015; 3: 69-78.

14.Zhou Y, Zhou L, Fu C, et al. Socio-economic factors related with the subjective well-being of the rural elderly people living independently in China. Int J Equity Health. 2015; 14: 5.

15. Waszkiewicz L, Połtyn-Zaradna K, Einhorn J, et al. Subjective assessment of health and quality of life of older Poles. Polityka Społeczna. 2011; 4 52-59.

16. Frąckowiak T. The sense of the quality of life for long-lived people. Dev Psychol. 2012; 17(1): 101-105.

17. Pacian, A, Kulik TB, Chruściel P, et al. Quality of life and risk of depression among elderly people. Hyg Pub Health 2014; 49(4): 820-824.

18. Kirchengast S, Haslinger B. Gender differences in health-related quality of life among healthy aged and old-aged Austrians: cross-sectional analysis. Gender Medicine. 2008; 5(3): 270-278.

19. Blay SL, Marchesoni MSM. Association among physical, psychiatric and socioeconomic conditions and WHOQOL-Bref scores. Cad Saúde Pública. 2011; 7: 677-686.

20. Canković S, Nikolić EA, Jovanović VM, et al. Quality of life of elderly people living in a retirement home. Vojnosanit Pregl. 2016; 73(1): 42-46.
21. Ganesh Kumar S, Majumdar A, Pavithra G. Quality of life (QOL) and its associated factors using WHOQOL-BREF among elderly in urban Puducherry, India. J Clin Diagn Res. 2014; 8(1): 54-57.

22. Arslantas D, Unsal A, Metintas S, et al. Life quality and daily life activities of elderly people in rural areas, Eskişehir (Turkey). Arch Gerontol Geriat. 2009; 48(2): 127-131.

23. Pawlikowska-Łagód K, Dąbska O, Humeniuk E. Satisfaction with the lives of older people living in Lublin Province. Geriatria. 2017; 11: 183-189.

24. Timoszyk-Tomczak C, Bugajska B. Life satisfaction and the perspective of the future in senility. Opuscula Sociologica 2013; 2(4): 83-95.

25. Uma Devi L, Kavitha Kiran V, Swachita, P. Satisfaction with life in elderly with reference to gender, age and residence. IOSR J Hum Soc Sci. 2015; 20: 57-59.

26. Nowicki GJ, Młynarska M, Ślusarska B, et al. Life satisfaction in patients aged 65 years plus treated at primary care settings dependent on selected sociodemographic characteristics. Polish Gerontology. 2016; 24(4): 264-268.

27. Mirczak A, Pikuła N. Life satisfaction of the elderly living in selected rural areas of the Malopolska region. Nursing and Public Health. 2014; 4(4): 321-326.

28. Mudyń K, Weiss A. Life satisfaction of people at senior age versus life orientations and declared values. Społeczeństwo i Rodzina 2010; 22(1): 1-18.

29. Forlani C, Morri M, Ferrari B, et al. Prevalence and gender differences in late-life depression: a population-based study. Am J Geriatr Psychiatry. 2014; 22(4): 370-380.

30. Fidecki W, Wysokiński M, Wrońska I, et al. Risk assessment of depression among the elderly from a rural environment. Geriatria. 2019; 13: 147-151.

31. Back JH, Lee Y. Gender differences in the association between socioeconomic status (SES) and depressive symptoms in older adults. Arch Gerontol Geriat. 2011; 52(3): 140-144.

32. Lin PC, Wang HH. Factors associated with depressive symptoms among older adults living alone: an analysis of sex. Aging Ment Health. 2011; 15(8): 1038-1044.

33. Lohman M, Dumenci L, Mezuk B. Sex differences in the construct overlap of frailty and depression: evidence from the health and retirement study. J Am Geriatr Soc. 2014; 62(3): 500-505.

34. Dalal PK, Agarwal M. Postmenopausal syndrome. Indian Journal of Psychiatry. 2015; 57: 222-232.

35. Djukanović I, Sorjonen K, Peterson U. Association between depressive symptoms and age, sex, loneliness and treatment among older people in Sweden. Aging Ment Health. 2015; 19(6): 560-568.

36. Park JH, Kim KW, Kim MH, et al. A nationwide survey on the prevalence and risk factors of late life depression in South Korea. J Affect Disord. 2012; 138(1-2): 34-40.

37. Bartoszek A, Kocka K, Ślusarska B. Functional efficiency and life events, and intensity of depression-associated symptoms among seniors living in home environment. Medycyna Rodzinna. 2018; 21(1): 10-15.

38. Ślusarska B, Nowicki GJ, Bartoszek A, et al. Health problems of the elderly aged 65-75 years supervised by a community nurse. Polish Gerontology. 2016; 24: 17-25.

39. Chang YC, Yao G, Hu SC, et al. Depression affects the scores of all facets of the WHOQOL-BREF and may mediate the effects of physical disability among community-dwelling older adults. PLoS One. 2015; 10(5): e0128356.

40. Patten SB, Williams JVA, Lavorato DH, et al. Recreational physical activity ameliorates some of the negative impact of major depression on health-related quality of life. Front Psychiatry. 2013; 2: 22. 